\title{
Determination of Malaysian Herbs and Spices as Biopreservative Agents in Food Products
}

\author{
Saripah Salbiah Syed Abdul Azziz ${ }^{*}$, Munirah Abdul Talip1, Chee Fah Wong², \\ Hasimah Alimon'2, Norlaili Abu Bakar1, Wan Rusmawati Wan Mahamod', \\ Rozita Yahaya1, Mohamad Syahrizal Ahmad', Yusnita Juahir' \\ ${ }^{1}$ Department of Chemistry, Faculty of Science and Mathematics, Universiti Pendidikan Sultan Idris, Tanjung \\ Malim, Perak, Malaysia \\ ${ }^{2}$ Department of Biology, Faculty of Science and Mathematics, Universiti Pendidikan Sultan Idris, Tanjung Malim, \\ Perak, Malaysia \\ Email: saripah@fsmt.upsi.edu.my
}

Received 12 February 2015; accepted 18 March 2015; published 23 March 2015

Copyright (C) 2015 by authors and Scientific Research Publishing Inc.

This work is licensed under the Creative Commons Attribution International License (CC BY). http://creativecommons.org/licenses/by/4.0/

c) (7) Open Access

\begin{abstract}
Preservatives are usually added to food products to ensure longer shelf life and prevent decomposition process and microbial growth. However, synthetic food preservatives can also give negative side effect to health and are harmful to human and animal physiology. Based on the potential of herbs and spices as antimicrobial agent, the purpose of this study is to identify antibacterial activity from extracts of some local herbs and spices: Phaeomeria speciosa (P. speciosa), Aquilaria subintegra (A. subintegra), Polygonum minus (P. minus), Syzygium aromaticum (S. aromaticum), Cinnamomum verum (C. verum) and Piper nigrum ( $P$. nigrum) against food bacteria using disc diffusion method. Results revealed that dichloromethane extracts of $C$. verum, hexane extracts of $S$. aromaticum and $P$. minus showed the most active antibacterial against tested bacteria. The Minimal Inhibitory Concentrations (MIC) ranged from 25 to $75 \mathrm{mg} / \mathrm{ml}$ for dichloromethane extract of $C$. verum, hexane extract of $S$. aromaticum and $P$. minus. Therefore further research should be pursued to identify the chemical structure of antibacterial agents from the active extracts as an alternative source of natural preservatives.
\end{abstract}

\section{Keywords}

Preservative Agents, Antibacterial Activity, Disc Diffusion Assay, MIC

\footnotetext{
${ }^{*}$ Corresponding author.
}

How to cite this paper: Azziz, S.S.S.A., Talip, M.A., Wong, C.F., Alimon, H., Bakar, N.A., Mahamod, W.R.W., Yahaya, R., Ahmad, M.S. and Juahir, Y. (2015) Determination of Malaysian Herbs and Spices as Biopreservative Agents in Food Products. American Journal of Plant Sciences, 6, 718-724. http://dx.doi.org/10.4236/ajps.2015.65077 


\section{Introduction}

Preservatives are crucial in food manufacturing, cosmetics, medicine and pharmaceutical products to extend their shelf life and avoid the growth of bacteria. Besides that, preservation also plays an important role in the taste, colour and texture as well as improves nutrition value of the foods. The source of preservatives can be natural or synthetic. Preservatives from natural sources such as herbs and spices have long been practiced in traditional food and medicinal preparations, and recent studies have shown their potential as antibacterial, antifungal, antiviral and antioxidant agents [1]. Essential oils from herbs and spices such as clove, coriander, garlic, rosemary, thyme, onion and sage had been found to have strong antimicrobial activities [2]. Cinnamon and clove extracts also showed significant inhibition zones against Staphylococcus aureus by using disc diffusion technique [1]. Antimicrobial property of an extract is determined by the chemical composition, structure and functional group of a compound [2]. Most phenolic compounds, polyphenols, alkaloids, terpenes and flavonoids from plant extract had been reviewed as antimicrobial agents [3]-[5].

On the other hand, synthetic preservatives synthesized through chemical reactions produce cheaper alternative and now are becoming more reliable and in favour. Previous studies have shown that without proper management, synthetic food preservatives could give negative effect not only to human and animal health but also to the physiology of other living organisms, damage the biology system and pollute the environment [6]. A common example of synthetic preservative-sodium benzoate is a salt from benzoic acid widely used to preserve pickle, sauce and fruit juice. However, this substance can cause skin irritation and cancer [7]. A study on synthetic preservative had been done on rats and found that sodium benzoate gives bad effect to their nervous system [8]. In comparison, natural preservative had been reported to be safer and more effective [9]. Nevertheless to optimize the action of natural preservatives, the extraction process is imperative.

Solvent used for plant extraction will determine the compound extracted and its bioactivity. The solvent can be grouped into different polarities which are low, medium and high polarity [10]. Solvent in low polarity hexane is usually used to extract waxes, fats and volatile oils. Medium polarity dichloromethane solvent is used to extract alkaloids, aglycones and volatile oil while high polarity solvent, such as methanol and water, is used to extract sugars, amino acids and also glycosides. Hence, this study will work on different polarities of solvent used for plant extraction and investigate the potential of each extract against common bacteria that usually are found in spoilt foods such as Escherichia coli, Staphylococcus aureus, Bacillus cereus, Salmonella typhi and Pseudomonas aeruginosa.

\section{Materials and Method}

\subsection{Plant Material}

P. speciosa, A. subintegra, and P. minus were collected around Tanjung Malim, Perak while S. aromaticum, C. verum and $P$. nigrum were purchased from the local market in Behrang, Perak in 2013. Plant species and their parts used in this study were summarized in Table 1. Plant materials were separated, cut into small pieces and oven-dried at $40^{\circ} \mathrm{C}$. The dried plant materials were ground into powder using grinder machine.

\subsection{Plant Extraction}

Powdered samples were sequentially extracted with hexane, dichloromethane and methanol by maceration tech-

Table 1. Plant species and the plant parts used.

\begin{tabular}{ccc} 
Plant species & Parts used & Remarks \\
\hline Phaeomeria speciosa & Flowers & Only widely open petals were chosen \\
Aquilaria subintegra & Young leaves & Healthy young leaves were chosen \\
Polygonum minus Huds. & Leaves & Only healthy and green leaves were chosen \\
Syzygium aromaticum & Buds & Brownish and dry buds were chosen \\
Cinnamomum verum & Stem barks & Light reddish brown barks were chosen \\
Piper nigrum & Drupes & Only dried and black drupes were chosen
\end{tabular}


nique at room temperature for 72 hours and then extract with water by reflux technique for two hours to avoid deterioration of the chemical compounds. The organic extracts (18 extracts) were evaporated in vacuum by using rotary evaporator at $40^{\circ} \mathrm{C}$ while the water extracts (6 extracts) were freeze-dried. The dried extracts were stored in glass bottle at $4^{\circ} \mathrm{C}$ for further analysis.

\subsection{Antimicrobial Activity}

\subsubsection{Microorganisms}

Bacteria cultures of Escherichia coli, Bacillus cereus, Pseudomonas aeruginosa, Staphylococcus aureus and Salmonella typhi were obtained from culture collection centre, Department of Biology, Universiti Pendidikan Sultan Idris, Perak, used for antibacterial test microorganisms. All bacteria strains were maintained and grown according to standard procedures, unless otherwise stated.

\subsubsection{Disc Diffusion Method}

After overnight incubation in nutrient broth at $37^{\circ} \mathrm{C}$, a sterile cotton swab was dipped into each nutrient broth suspension containing the tested bacteria; E. coli, B. cereus, P. aeruginosa, S. aureus and S. typhi, were swab on the agar surface. Then the $5 \mathrm{~mm}$-diameter sterile filter paper discs were impregnated with different concentration of extracts and a control. The antibacterial test was done at concentration 25, 50, 75 and $100 \mathrm{mg} / \mathrm{ml}$. Methanol and distilled water that used to dilute the extract were choose as the control. Then, they were placed on the NA plate with suitable distance from each other. The discs were gently pressed down by using sterile forcep to ensure complete contact with agar surface. The plates were then sealed with parafilm and incubated at $37^{\circ} \mathrm{C}$ overnight in inverted to prevent the moisture build up on the lid from dripping onto the bacteria. Observations were recorded after 24 hours incubation. Antibacterial activities were interpreted from the diameters of inhibition zone around the disc and done in triplicate [11].

\subsection{Determination of Minimal Inhibitory Concentration (MIC)}

The minimal inhibitory concentration was performed on extracts which showed zone of inhibition in the preliminary screening by using dilution method according to Nascimento et al. [12]. MIC of selected extracts was determined by measuring the optical density at $620 \mathrm{~nm}$ by comparing the reading of nutrient broth added with extract and inoculated with tested bacteria, with the nutrient broth added with extract without the tested bacteria as control. Each MIC determination was carried out in triplicate.

\section{Results and Discussion}

\subsection{Disc Diffusion Test}

The disc diffusion method was used to evaluate the antibacterial activity. In this study, 18 organic extracts and 6 water extracts from P. speciosa, A. subintegra, P. minus, S. aromaticum, P. nigrum and C. verum were tested against Gram negative bacteria, E. coli, S. typhi, P. aeruginosa and Gram positive bacteria, B. cereus and S. aureus which commonly found in food such as chilli sauce. Four out of six herbs and spices tested in this study have shown antibacterial activity by using disc diffusion method (Table 2). Nor organic neither water extracts from $P$. speciosa and $P$. nigrum showed any antibacterial activity. Only methanol extracts of A. subintegra at higher concentration (75 mg/ml and $100 \mathrm{mg} / \mathrm{ml}$ ) showed inhibition zone to only P. aeruginosa. Aqueous extracts of $P$. minus did not show any antibacterial activities against all bacteria tested.

A study carried out on pure piperine isolated from $P$. nigrum's drupes showed zone of inhibition against $E$. coli, $P$. aeruginosa and $S$. aureus [13]. P. nigrum's extracts in this study were found not active against all tested bacteria. The difference result obtained probably caused by antagonistic effect of the compound where the pure single compound inhibition effect is greater than the combination of compound mixture in an extract [14].

Other than environmental condition, genetic factor, solvent used for extraction also affects the degree of antibacterial activity [15] [16]. Previous study of water extract from $P$. speciosa showed inhibition against $S$. aureus and other bacteria including Staphylococcus xylosus and Micrococcus species [17]. However, P. speciosa from this study were found not active against all the tested bacteria. Method of extraction in this study might be affecting the antibacterial activity of $P$. speciosa because the compound had been extracted serially in different polarity solvents. The composition of bioactive compounds from plant material will depend on the types and 
Table 2. Antibacterial activity of different extracts from P. minus Huds., S. aromaticum and C. verum.

\begin{tabular}{|c|c|c|c|c|c|c|c|}
\hline \multirow{2}{*}{ Plants } & \multirow{2}{*}{ Extracts } & \multirow{2}{*}{ Test bacteria } & \multicolumn{5}{|c|}{ Conc. $(\mathrm{mg} / \mathrm{ml}) /$ Zone of inhibition $(\mathrm{mm} \pm \mathrm{s.d})$} \\
\hline & & & $\mathbf{0}$ & 25 & 50 & 75 & 100 \\
\hline \multirow[t]{12}{*}{ A. subintegra } & \multirow[t]{7}{*}{$\mathrm{MeOH}$} & E. coli & - & - & - & - & - \\
\hline & & S. aureus & - & - & - & - & - \\
\hline & & S. typhi & - & - & - & - & - \\
\hline & & B. cereus & - & - & - & - & - \\
\hline & & P. aeruginosa & - & - & - & $6.67 \pm 0.58$ & $7.00 \pm 0.00$ \\
\hline & & E. coli & - & - & - & - & - \\
\hline & & S. aureus & - & $6.67 \pm 0.58$ & $7.33 \pm 0.58$ & $7.67 \pm 0.58$ & $7.67 \pm 0.58$ \\
\hline & \multirow[t]{5}{*}{ Hex } & S. typhi & - & - & - & - & - \\
\hline & & B. cereus & - & $7.00 \pm 0.00$ & $8.00 \pm 0.00$ & $8.67 \pm 0.58$ & $9.33 \pm 0.58$ \\
\hline & & P. aeruginosa & - & $7.67 \pm 0.58$ & $8.67 \pm 0.58$ & $9.00 \pm 1.00$ & $9.33 \pm 0.58$ \\
\hline & & E. coli & - & - & - & - & - \\
\hline & & S. aureus & - & - & - & - & - \\
\hline \multirow[t]{13}{*}{ P. minus Huds. } & \multirow[t]{5}{*}{ DCM } & S. typhi & - & - & - & - & - \\
\hline & & B. cereus & - & - & - & $6.67 \pm 0.58$ & $6.67 \pm 0.58$ \\
\hline & & P. aeruginosa & - & - & $6.33 \pm 0.58$ & $6.67 \pm 0.58$ & $7.67 \pm 0.58$ \\
\hline & & E. coli & - & - & - & - & - \\
\hline & & S. aureus & - & - & - & $6.67 \pm 0.58$ & $7.33 \pm 1.15$ \\
\hline & \multirow[t]{5}{*}{$\mathrm{MeOH}$} & S. typhi & - & - & - & - & - \\
\hline & & B. cereus & - & - & - & $6.33 \pm 0.58$ & $6.67 \pm 0.58$ \\
\hline & & P. aeruginosa & - & - & $6.67 \pm 0.58$ & $6.67 \pm 0.58$ & $7.00 \pm 0.00$ \\
\hline & & E. coli & - & $7.33 \pm 0.58$ & $7.00 \pm 1.00$ & $7.60 \pm 0.58$ & $8.00 \pm 0.00$ \\
\hline & & S. aureus & - & $7.00 \pm 0.00$ & $8.67 \pm 0.58$ & $9.00 \pm 1.00$ & $9.00 \pm 1.00$ \\
\hline & \multirow[t]{5}{*}{ Hex } & S. typhi & - & $6.33 \pm 0.58$ & $7.00 \pm 0.00$ & $7.67 \pm 1.15$ & $9.00 \pm 1.00$ \\
\hline & & B. cereus & - & $7.00 \pm 0.00$ & $8.33 \pm 0.58$ & $8.33 \pm 0.58$ & $9.00 \pm 0.00$ \\
\hline & & P. aeruginosa & - & $6.33 \pm 0.58$ & $7.00 \pm 0.00$ & $7.60 \pm 0.58$ & $8.00 \pm 0.00$ \\
\hline \multirow{8}{*}{ S. aromaticum } & & E. coli & - & - & - & - & $7.00 \pm 0.00$ \\
\hline & & S. aureus & - & - & - & - & $7.00 \pm 1.00$ \\
\hline & \multirow[t]{5}{*}{ DCM } & S. typhi & - & - & - & - & - \\
\hline & & B. cereus & - & - & - & - & - \\
\hline & & P. aeruginosa & - & - & $7.00 \pm 1.73$ & $6.67 \pm 1.15$ & $7.67 \pm 0.58$ \\
\hline & & E. coli & - & - & - & $7.00 \pm 1.00$ & $8.00 \pm 0.00$ \\
\hline & & S. aureus & - & $7.67 \pm 0.58$ & $7.67 \pm 0.58$ & $7.67 \pm 1.15$ & $8.00 \pm 1.00$ \\
\hline & \multirow[t]{3}{*}{ Hex } & S. typhi & - & $7.00 \pm 0.00$ & $7.33 \pm 0.58$ & $8.33 \pm 0.58$ & $9.00 \pm 1.00$ \\
\hline \multirow[t]{4}{*}{ C. verum } & & B. cereus & - & $7.00 \pm 0.00$ & $7.67 \pm 0.58$ & $11.00 \pm 0.00$ & $10.00 \pm 0.00$ \\
\hline & & P. aeruginosa & - & $7.00 \pm 0.00$ & $8.67 \pm 0.58$ & $11.00 \pm 0.00$ & $10.67 \pm 0.58$ \\
\hline & \multirow{2}{*}{ DCM } & E. coli & - & - & - & - & - \\
\hline & & S. aureus & - & - & $7.00 \pm 0.00$ & $8.33 \pm 0.58$ & $9.00 \pm 1.00$ \\
\hline
\end{tabular}


Continued

\begin{tabular}{|c|c|c|c|c|c|c|c|}
\hline & & S. typhi & - & - & - & $6.67 \pm 0.58$ & $7.67 \pm 0.58$ \\
\hline & & B. cereus & - & $8.00 \pm 1.00$ & $10.67 \pm 0.58$ & $14.00 \pm 1.73$ & $13.67 \pm 1.15$ \\
\hline & & P. aeruginosa & - & $9.00 \pm 0.00$ & $11.33 \pm 0.58$ & $13.33 \pm 2.52$ & $14.33 \pm 1.53$ \\
\hline & & E. coli & - & - & - & - & - \\
\hline & & S. aureus & - & $6.00 \pm 0.00$ & $7.00 \pm 1.00$ & $7.33 \pm 0.58$ & $7.00 \pm 0.00$ \\
\hline & $\mathrm{MeOH}$ & S. typhi & - & - & - & - & - \\
\hline \multirow[t]{7}{*}{ C. verum } & & B. cereus & - & $6.33 \pm 0.58$ & $7.00 \pm 1.00$ & $7.67 \pm 0.58$ & $8.67 \pm 0.58$ \\
\hline & & P. aeruginosa & - & $7.33 \pm 0.58$ & $9.00 \pm 1.00$ & $10.33 \pm 0.58$ & $10.33 \pm 0.58$ \\
\hline & & E. coli & - & - & - & - & - \\
\hline & & S. aureus & - & - & $7.00 \pm 1.00$ & $8.33 \pm 0.58$ & $8.67 \pm 0.58$ \\
\hline & Aqueous & S. typhi & - & - & - & - & - \\
\hline & & B. cereus & - & $8.00 \pm 0.00$ & $8.67 \pm 0.58$ & $9.67 \pm 0.58$ & $10.00 \pm 0.00$ \\
\hline & & P. aeruginosa & - & $7.00 \pm 0.00$ & $8.33 \pm 0.58$ & $9.33 \pm 0.58$ & $9.33 \pm 0.58$ \\
\hline
\end{tabular}

Key: Hex = Hexane, DCM = Dichloromethane, $\mathrm{MeOH}=$ Methanol $(\mathrm{n}=3),(-)=$ No zone of inhibition.

polarity of solvent used for extraction. A polar compound will extracted by polar solvent and non-polar compound will extracted by non-polar solvent. Thus, the biological activity shown may be different between extracts since different compounds will be extracted [18]. For example, Qader et al. [19] reported that $P$. minus have antibacterial properties against $H$. pylori when extract using petroleum ether, chloroform and methanol. However, aqueous extract of $P$. minus showed no inhibition against $H$. pylori.

Interestingly, hexane extract of $C$. verum and S. aromaticum showed antibacterial properties against all five tested organisms while hexane extract from $P$. minus gave positive result against three bacteria; $S$. aureus, $B$. cereus and $P$. aeruginosa. Even though essential oil is usually extracted by steam distillation technique, in this study, essential oil, waxes and fats might be dissolved in non polar solvent such as hexane [10] (Peter and Amala, 1998) and showed good antibacterial activity based on the zone of inhibition exhibited, range from $7 \mathrm{~mm}$ to $11 \mathrm{~mm}$ in diameter (Table 2). In previous study, ethanol extract of $P$. minus was found to be active as antimicrobial against Gram-positive bacteria; Bacillus cereus and Bacillus megaterium, two Gram-negative bacteria; Escherichia coli and Pseudomonas aeruginosa, and two fungi; Aspergillus ochraceous and Cryptococcus neoformans [20] (Macken et al., 1997). In present study, dichloromethane extracts from P. minus showed inhibition against $B$. cereus and $P$. aeruginosa while $S$. aromaticum showed positive results against $E$. coli, $S$. aureus and $P$. aeruginosa. In addition, dichloromethane extract from $C$. verum gave positive results against $S$. aureus, $S$. typhi, B. cereus and P. aeruginosa. Methanol extracts from C. verum and P. minus showed antibacterial activity against $S$. aureus, B. cereus and $P$. aeruginosa while methanol extract of $S$. aromaticum showed no inhibition against all the tested bacteria. Water extract from $C$. verum showed inhibition against $S$. aureus, B. cereus and $P$. aeruginosa.

Previous studies indicate that eugenol and cinnamaldehyde, were two major chemical components found in the spice oil of Cinnamom species and S. aromaticum that showed inhibition against gram negative and gram positive bacteria [21] [22]. Eugenol is a phenolic compound with-OH group, which gives hydrophobicity of the molecule that enables to penetrate the lipopolysaccharide of the gram negative bacterial cell membrane and disturbed the cell structures [23]. Hence, this lead to the leakage of ions and other cell contents, which consequently inhibit the bacterial growth.

\subsection{Minimum Inhibition Concentration (MIC)}

The results from disc diffusion methods show three extracts that exhibited very active antibacterial activity; dichloromethane extract of $C$. verum, hexane extract of $S$. aromaticum and hexane extract of $P$. minus Huds. leaves (Table 2). They were further tested to determine the Minimal Inhibitory Concentration (MIC). The MIC values for the extracts were shown in Table 3. Plant extract of C. verum in dichloromethane showed MIC of 25 
Table 3. Minimum inhibitory concentraction (MIC) of dichloromethane extract of C. verum, hexane extract of S. aromaticum and hexane extract of $P$. minus Huds. from leaves.

\begin{tabular}{cccc}
\hline \multirow{2}{*}{ Test organisms } & \multicolumn{3}{c}{ Extracts/Minimum inhibition concentration (mg/ml) } \\
\cline { 2 - 4 } & DCM extract of $C$. verum & Hex extract of S. aromaticum & Hex extract of $P$. minus Huds. \\
\hline E. coli & - & 25 & - \\
S. aureus & 25 & 25 & 25 \\
S. typhi & 50 & 75 & 25 \\
B. cereus & 25 & 50 & 25 \\
P. aeruginosa & 25 & 25 & 25 \\
\hline
\end{tabular}

$\mathrm{mg} / \mathrm{ml}$ against tested bacteria S. aureus, B. cereus and P. aeruginosa, whereas $50 \mathrm{mg} / \mathrm{ml}$ for $S$. typhi. Hexane extract of S. aromaticum showed MIC of $25 \mathrm{mg} / \mathrm{ml}$ against E. coli, S. aureus and P. aeruginosa, whereas 50 $\mathrm{mg} / \mathrm{ml}$ against $B$. cereus and $75 \mathrm{mg} / \mathrm{ml}$ against $S$. typhi. The MIC of $25 \mathrm{mg} / \mathrm{ml}$ was obtained against $S$. aureus, $B$. cereus and $P$. aeruginosa when tested with hexane extract of $P$. minus Huds. From the results, antibacterial activity of the selected herbs and spices against both gram positive and gram negative bacteria show the presence of broad-spectrum antibacterial properties. Therefore, it is hypothesized that this local herbs and spices can be used as biopreservative agent in food products.

\section{Conclusion}

Herbs, spices and edible plants have long been given most attention for their medicinal properties and low toxicity to human. They also show potential as antibacterial agents that are relatively safer than synthetic alternatives like sodium benzoate. From the findings, the most significant antibacterial activities were found in all four extracts of $C$. verum, hexane extracts of $S$. aromaticum and $P$. minus Huds. which can form basis information for further studies. Hence, these herbs and spices that are of interest for antibacterial agents are suggested for further study on toxicity testing, further isolation of active compounds, identification of its chemical structure and evaluation against a wider range of biological activities like in vivo testing with the aim for use in food preservation.

\section{Acknowledgements}

The authors acknowledge Ministry of Higher Education, Malaysia and Universiti Pendidikan Sultan Idris (UPSI) for provision of financial support for this research work, FRGS (2014-0030-101-02) and GPU (2013-0068102-01).

\section{References}

[1] Zainab, A.A.D. (2008) The Antibacterial Activity of Aqueous Extract of Cinnamon and Clove against Staphylococcus aureus. Journal of Al-Nahrain University, 11, 131-135.

[2] Coisin, M., Burzo, I., Stefan, M., Rosenhech, E. and Zamfirache, M.M. (2012) Chemical Composition and Antibacterial Activity of Essential Oils of Three Salvia Species, Widespread in Eastern Romania. Biologie Vegetală, 58, 51-58.

[3] Pereira, A.P., Ferreira, I.C.F.R., Marcelino, F., Valentao, P., Andrade, P.B., Seabra, R., Estevinho, L., Bento, A. and Pereira, J.A. (2007) Phenolic Compounds and Antimicrobial Activity of Olive (Olea europaea L. Cv. Cobrançosa) Leaves. Molecules, 12, 1153-1162. http://dx.doi.org/10.3390/12051153

[4] Hendra, R., Ahmad, S., Sukari, A., Shukor, M.Y. and Oskoueian, E. (2011) Flavonoid Analyses and Antimicrobial Activity of Various Parts of Phaleria macrocarpa (Scheff.) Boerl Fruit. International Journal of Molecular Sciences, 12, 3422-3431. http://dx.doi.org/10.3390/ijms12063422

[5] Pfoze, N.L., Kumar, Y., Myrboh, B., Bhagobaty, R.K. and Joshi, S.R. (2011) In Vitro Antibacterial Activity of Alkaloid Extract from Stem Bark of Mahonia manipurensis Takeda. Journal of Medicinal Plants Research, 5, 859-861.

[6] Newton, D.E. (2007) The New Chemistry: Food Chemistry. An Imprint of Infobase Publishing, USA.

[7] Anand, S.P. and Sati, N. (2013) Artificial Preservatives and Their Harmful Effects Looking toward Nature for Safer Alternatives. International Journal of Pharmaceutical Sciences and Research, 4, 2496-2501.

[8] Wibbertmann, A., Kielhorn, J., Koennecker, G., Mangelsdorf, I. and Melber, C. (2000) Benzoic Acid and Sodium 
Benzoate. World Health Organization, Geneva, 1-46.

[9] Sunilson, J.A.J., Suraj, R., Rejitha, G., Anandarajagopal, K., Kumari, A.V.G. and Promwichit, P. (2009) In Vitro Antimicrobial Evalution of Zingiber officinale, Curcuma longa and Alpinia galanga Extracts as Natural Food Preservatives. American Journal of Food Technology, 4, 192-200. http://dx.doi.org/10.3923/ajft.2009.192.200

[10] Peter, J.H. and Amala, R. (1998) Laboratory Handbook For the Fractionation of Natural Extracts. Chapman \& Hall. London.

[11] Niederstebruch, N. and Sixt, D. (2013) Standard Nutrient Agar 1 as a Substitute for Blood-Supplemented Müller-Hinton Agar for Antibiograms in Developing Countries European. Journal of Clinical Microbiology \& Infectious Disease, 32, 237-241. http://dx.doi.org/10.1007/s10096-012-1735-2

[12] Nascimento, G.G.F., Locatelli, J., Freitas, P.C. and Silva, G.L. (2000) Antibacterial Activity of Plant Extracts and Phytochemicals on Antibiotic-Resistant Bacteria. Brazilian Journal of Microbiology, 31, 247-256. http://dx.doi.org/10.1590/S1517-83822000000400003

[13] Zainab, T.K.A. (2010) Antimicrobial Activity of Piperine Purified from Piper nigrum. Journal of Basrah Researchers (Sciences), 36, 50-61.

[14] Milugo, T.K., Omasa, L.K., Ochanda, J.O., Owuor, O.B, Wamunyokoli, F.A., Oyugi, J.O. and Ochieng, J.W. (2013) Antagonistic Effect of Alkaloids and Saponins on Bioactivity in the Quinine Tree (Rauvolfia caffra Sond.): Further Evidence to Support Biotechnology in Traditional Medicinal Plants. BMC Complementary and Alternative Medicine, 13, 285-291. http://dx.doi.org/10.1186/1472-6882-13-285

[15] Aprotosoaie, A.C., Spac, A., Hancianu, M., Miron, A., Tanasescu, V.F., Dorneanu, V. and Stanescu, U. (2010) The Chemical Profile of Essential Oils Obtained from Fennel Fruits (Foeniculum vulgare Mill.). Farmacia, 58, 46-53.

[16] Idamokoro, E.M., Masika, P., Munchenje, V. and Green, E. (2013) In-Vitro Antibacterial Sensitivity of Usnea barbata Lichen Extracted with Methanol and Ethyl-Acetate against Selected Staphylococcus Species from Bovine Milk. Mendelnet, 203-206.

[17] Nurain, A., Noriham, A.Z.M.N., Wan Saidatul, S.W.K. and Khairusy, S.Z. (2012) Phytochemical Constituents and Bioactivities of Aqueous Extract of Aromatic Herbs. International Journal of PharmTech Research, 4, 1401-1406.

[18] Rasooli, I. (2007) Food Preservation-A Biopreservative Approach. Food, 1, 111-136.

[19] Qader, S.W., Abdulla, M.A., Chua, L.S. and Hamdan, S. (2012) Potential Bioactive Property of Polygonum minus Huds (Kesum) Review. Scientific Research and Essays, 7, 90-93.

[20] Macken, M.M., Ali, A.M., El-Sharkawy, S.H., Manap, M.Y., Salleh, K.M., Lajis, N.H. and Kawazu, K. (1997) Antimicrobial and Cytotoxic Properties of Some Malaysian Traditional Vegetables (Ulam). Pharmaceutical Biology, 35, 174-178. http://dx.doi.org/10.1076/phbi.35.3.174.13294

[21] Alexander, O.G. and Richard, A.H. (2004) Mechanisms of Bactericidal Action of Cinnamaldehyde against Listeria monocytogenes and of Eugenol against L. monocytogenes and Lactobacillus sakei. Applied and Environmental Microbiology, 70, 5750-5755. http://dx.doi.org/10.1128/AEM.70.10.5750-5755.2004

[22] Sanla-Ead, N., Jangchud, A., Chonhenchob, V. and Suppakul, P. (2012) Antimicrobial Activity of Cinnamaldehyde and Eugenol and Their Activity after Incorporation into Cellulose-Based Packaging Films. Packaging Technology and Science, 25, 7-17. http://dx.doi.org/10.1002/pts.952

[23] Hyldgaard, M., Mygind, T. and Meyer, R.L. (2012) Essential Oils in Food Preservation: Mode of Action, Synergies, and Interactions with Food Matrix Component. Frontiers in Microbiology, 3, 1-24. http://dx.doi.org/10.3389/fmicb.2012.00012 